\title{
Antibiotic Susceptibility and Biofilm Formation of Clinical Isolates of Pseudomonas Species from Wounds Specimens
}

\author{
Mercy Ugbede Enemali ${ }^{1}$, Danung Istifanus Yilkahan ${ }^{1}$
}

${ }^{1}$ Department of Natural and applied science ATBU Bauchi, Nigeria

\begin{tabular}{|c|c|}
\hline Article Info & Abstract \\
\hline Article history: & Purpose: The aim of the study is to investigate biofilm forming capacity \\
\hline Received:22 June 2021 & biotic susceptibility profile of Pseudomonas aeruginosa strains \\
\hline Revised: 07 August 2021 & imens were submitted to the \\
\hline Accepted:11 August 2021 & bacteriology laboratory of Abubakar Tafawa Balewa University Teaching \\
\hline Keywords: & $\begin{array}{l}\text { Hospital for investigation, and screened for Pseudomonas aeruginosa. The } \\
\text { strains were identified on the basis of cultural characteristics, Gram }\end{array}$ \\
\hline Antibiotic Susceptibility, & staining, biochemical tests such as citrate, urease, indole, fermentation of \\
\hline Antibiotics, & sugar using triple sugar agar. The biofilm forming capacity of the strains \\
\hline $\begin{array}{l}\text { Fermentation, } \\
\text { Clinical Isolates }\end{array}$ & $\begin{array}{l}\text { are tested using the test tube method after standardizing the strains to } \\
\text { anproximately standard inoculated into a cooked meat broth. The growth }\end{array}$ \\
\hline 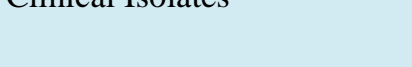 & rate of Pseudomonas aeruginosa clinical strains after 48 hours incubation \\
\hline Par & are measured by taking the absorbance using Densi-Check. The strain \\
\hline Research Article & $\begin{array}{l}\text { growth rate is also checked. Biofilm formation at the liquid interface } \\
\text { (pellicle) is qualitatively scored from the first to the last strain. The clinical }\end{array}$ \\
\hline Correspondence Author & $\begin{array}{l}\text { significance of the Pseudomonas aeruginosa biofilm forming capacity and } \\
\text { resistance to antibiotics which could result to none healing, delayed }\end{array}$ \\
\hline Mercy Ugbede Enemali & $\begin{array}{l}\text { healing, foul smell of wound infection are checked for the experiment. } \\
\text { Results: The analysis of the study shows that the strains are more }\end{array}$ \\
\hline Email: & $\begin{array}{l}\text { susceptible to Ciprofloxacin and Streptomycin while the strains are less } \\
\text { susceptible to Orfloxacin and Gentamycin. } \\
\text { Conclusion: the data derived from human clinical studies make clear that } \\
\text { biofilm have an important adverse effect on wound healing. Despite this, } \\
\text { more fundamental scientific studies are required to understand what biofilm } \\
\text { do to normal wound healing processes from cellular and immunological } \\
\text { perspective. }\end{array}$ \\
\hline
\end{tabular}

\section{Introduction}

The onset of wound infection depends on the integrity and protective function of the skin Anupurba et al., 2010). Infection is the outcome of the dynamic interaction that takes place between a host, potential pathogen and the environment (Mehta et al., 2007). It occurs when the host's defense strategies are successfully evaded by microorganism and results in deleterious changes in the host (Lambert et al., 2002). Complex interactions that are not yet fully understood precede the development of infection.

The widespread use of antibiotics, together with the length of time over which they have been available has led to major problems of resistant pathogens in wound infections, thus, contributing to morbidity and mortality. It has been shown that wound infection, is universal and 
the bacterial type varies with geographical location and resident flora of the skin (Anupubra et al., 2013).

Pseudomonas is a genius of Gram negative, aerobic Gammaproteobacteria, belonging to the family Pseudomonadaceae and containing 191 validly described species. They are Gram negative rod shaped and polar flagellated bacteria with some sporulating species.

A biofilm is any group of microorganism in which cells stick to each other and often these cells adhere to a surface. These adherent cells are frequently embedded within a self-produced matrix of extra cellular polymeric substance. Microscopic evaluation of specimens from chronic wound indicates presence of biofilm. Bacteria escape from biofilm that do not produce polysaccharide and are easily attacked by immune system cells. Inactivation of antibiotic takes place when bound to biofilm matrix. Pseudomonas has alginate exopoluysaccharide which is anionic in nature. Pseudomonas has a strong tendency to form biofilm which has been found to be partially responsible for chronic infection.

\section{Materials and Method}

\section{Sample collection}

Samples are collected from 60 patients with complaints of discharge, pain, swelling, foul smell, delayed and none healing wound infection. The wound sample were collected with the use of a sterile cotton swap, the linear surface of the infected wound will be swabbed gently and then the swab will be transported to the laboratory on a transport medium to the microbiology department of the Abubakar Tafawa Balewa University Teaching Hospital Bauchi.

\section{Isolation and Identification}

The isolates are collected and inoculated on Nutrient Agar and McConkey Agar aerobically at $37^{\circ} \mathrm{C}$ for 24 hours; it will then be sub cultured for discrete colonies. Discrete colonies that are lactose negative on McConkey Agar.

\section{Preservation}

Strains will be identified and then preserved on nutrient agar slant and will be preserved in the refrigerator at about $4^{\circ} \mathrm{C}$ for further use

\section{Biofilm formation test}

Cooked meat broth will be prepared for 24 hours, $3 \mathrm{ml}$ of the cooked meat broth will be transferred into a clean sterile test tube. A loop full of Pseudomonas colonies will be emulsified into the broth and incubated for 48 hours

\section{Antibiotics and Susceptibility Test}


Kirby-Bauer Disc diffusion method will be used to test the susceptibility of the Pseudomonas isolate to different antimicrobial agent. The test will be done on Mueller-Hinton agar using 0.5 McFarland standards for gram negative organism. Discrete colonies of Pseudomonas specie will be picked and emulsified on $3 \mathrm{ml}$ normal saline and inoculums; density will be checked using Densi-Check.

Spread plate will be used to obtain a confluence with the inoculated plate will be kept on the bench for 15 minutes to allow all moisture absorb and a Gram negative antibiotics discs will be placed on the culture without moving the disc after it is placed. The plate will be incubated for 24 hours at $37^{\circ} \mathrm{C}$ aerobically.

The result will be measured with the aid of a metre rule in two different directions across each inhibition zone as per clinical laboratory standards (CLSI, 2011). The isolate will thus be designated susceptible or resistant.

\section{Results And Discussion}

A total of 60 samples are collected form patients with wound infections attending the Abubakar Tafawa Balewa University, Bauchi.

Table 1: shows the biochemical test that will be carried out on the isolate Table 2: shows the Densi-Check (McFarland) standard of the inoculums

Table 3: shows the resistance and susceptibility pattern of the organism on the subjected antibiotics Table 4: shows the qualitative analysis of biofilm, formation

Table 5: shows the qualitative analysis absorbance of biofilm formation

Table 1: Biochemical Test

\begin{tabular}{|l|l|l|l|l|l|}
\hline & Indole & Citrate & Urea & TSI & \\
\hline Specie & & & & Slope & Butt \\
\hline PS1 & - & + & + & $\mathrm{R}$ & $\mathrm{R}$ \\
\hline PS2 & - & + & + & $\mathrm{R}$ & $\mathrm{R}$ \\
\hline PS3 & - & + & + & $\mathrm{R}$ & $\mathrm{R}$ \\
\hline PS4 & - & + & + & $\mathrm{R}$ & $\mathrm{R}$ \\
\hline PS5 & - & + & + & $\mathrm{R}$ & $\mathrm{R}$ \\
\hline PS6 & - & + & + & $\mathrm{R}$ & $\mathrm{R}$ \\
\hline PS7 & - & + & + & $\mathrm{R}$ & $\mathrm{R}$ \\
\hline PS8 & - & + & + & $\mathrm{R}$ & $\mathrm{R}$ \\
\hline PS9 & - & + & + & $\mathrm{R}$ & $\mathrm{R}$ \\
\hline
\end{tabular}

KEY: R-Red. PS-Pseudomonas specie 
Table 2: Density Check of the Inoculums (McFarland Standard)

\begin{tabular}{|l|l|l|l|l|l|}
\hline Number of Sample & & & & & Average \\
\hline PS1 & & & & & 0.52 \\
\hline PS2 & & & & & 0.47 \\
\hline PS3 & & & & & 0.50 \\
\hline PS4 & & & & & 0.47 \\
\hline PS5 & & & & & 0.52 \\
\hline PS6 & & & & & 0.48 \\
\hline PS7 & & & & & 0.47 \\
\hline PS8 & & & & & 0.52 \\
\hline PS9 & & & 0.51 \\
\hline
\end{tabular}

Key: PS- Pseudomonas specie

Table 3: Resistance ad Susceptibility of Antibiotics on the Organism

\begin{tabular}{|l|l|l|l|l|}
\hline ANTIBIOTICS & $\begin{array}{l}\text { CSLI } \\
\text { BREAK } \\
\text { POINT }\end{array}$ & $\begin{array}{l}\text { No OF } \\
\text { ISOLATE } \\
\text { TESTED }\end{array}$ & $\begin{array}{l}\text { SUSCEPTIBILITY } \\
\mathrm{n}=(\%)\end{array}$ & $\begin{array}{l}\text { RESISTANCE } \\
\mathrm{n}=(\%)\end{array}$ \\
\hline Augmenting & $\leq 16>$ & 9 & $0(0)$ & $9(100)$ \\
\hline Gentamycin & $\leq 12>$ & 9 & $4(44.4)$ & $5(55.5)$ \\
\hline Perfloxacin & $\leq 15>$ & 9 & $3(33.3)$ & $6(66.6)$ \\
\hline Orfloxacin & $\leq 14>$ & 9 & $4(44.4)$ & $5(55.5)$ \\
\hline Streptomycin & $\leq 11>$ & 9 & $8(88.8)$ & $1(11.1)$ \\
\hline Septrin & $\leq 15>$ & 9 & $0(0)$ & $9(100)$ \\
\hline Chloramphenicol & $\leq 17>$ & 9 & $0(0)$ & $9(100)$ \\
\hline Sparfloxacin & $\leq 15>$ & 9 & $2 .(22.2)$ & $7(77.7)$ \\
\hline Ciproflooxacin & $\leq 15>$ & 9 & $9(100)$ & $0(0)$ \\
\hline Amoxicilin & $\leq 15>$ & 9 & $2(22.2)$ & $7(77.8)$ \\
\hline
\end{tabular}

Table 4: Qualitative Analysis of Biofilm Formation

\begin{tabular}{|l|l|l|l|r|r|}
\hline $\begin{array}{l}\text { Number of } \\
\text { Sample }\end{array}$ & & & & & $\begin{array}{r}\text { Biofilm } \\
\text { Formation }\end{array}$ \\
\hline PS1 & & & & & +3 \\
\hline PS2 & & & & & +2 \\
\hline PS3 & & & & & +2 \\
\hline PS4 & & & & & +2 \\
\hline PS5 & & & & & +3 \\
\hline PS6 & & & & & +2 \\
\hline PS7 & & & & & +3 \\
\hline PS8 & & & & & +3 \\
\hline PS9 & & & & +3 \\
\hline
\end{tabular}

Key: PS- Pseudomonas specie 
Table 5: Qualitative Analysis of the absorbance of Pseudomonas strain

\begin{tabular}{|c|c|c|c|}
\hline PS & $\begin{array}{c}\text { ABSORBANCE AT } \\
\mathbf{5 9 0} \mathbf{~ n m}\end{array}$ & $\begin{array}{c}\text { ABSORBANCE AT } \\
\mathbf{5 9 0} \mathbf{~ n m}\end{array}$ & $\begin{array}{c}\text { MEAN AND STANDARD } \\
\text { DEVIATION }\end{array}$ \\
\hline 1 & 22 & 19 & $20.5 \pm 2.12$ \\
\hline 2 & 23 & 22 & $22.5 \pm 0.71$ \\
\hline 3 & 24 & 23 & $23.5 \pm 0.71$ \\
\hline 4 & 22 & 20 & $21 \pm 1.41$ \\
\hline 5 & 23 & 23 & $23 \pm 0.00$ \\
\hline 6 & 22 & 20 & $21 \pm 1.41$ \\
\hline 7 & 20 & 23 & $21.5 \pm 2.12$ \\
\hline 8 & 21 & 22 & $21.5 \pm 0.71$ \\
\hline 9 & 23 & 22 & $22.5 \pm 0.71$ \\
\hline
\end{tabular}

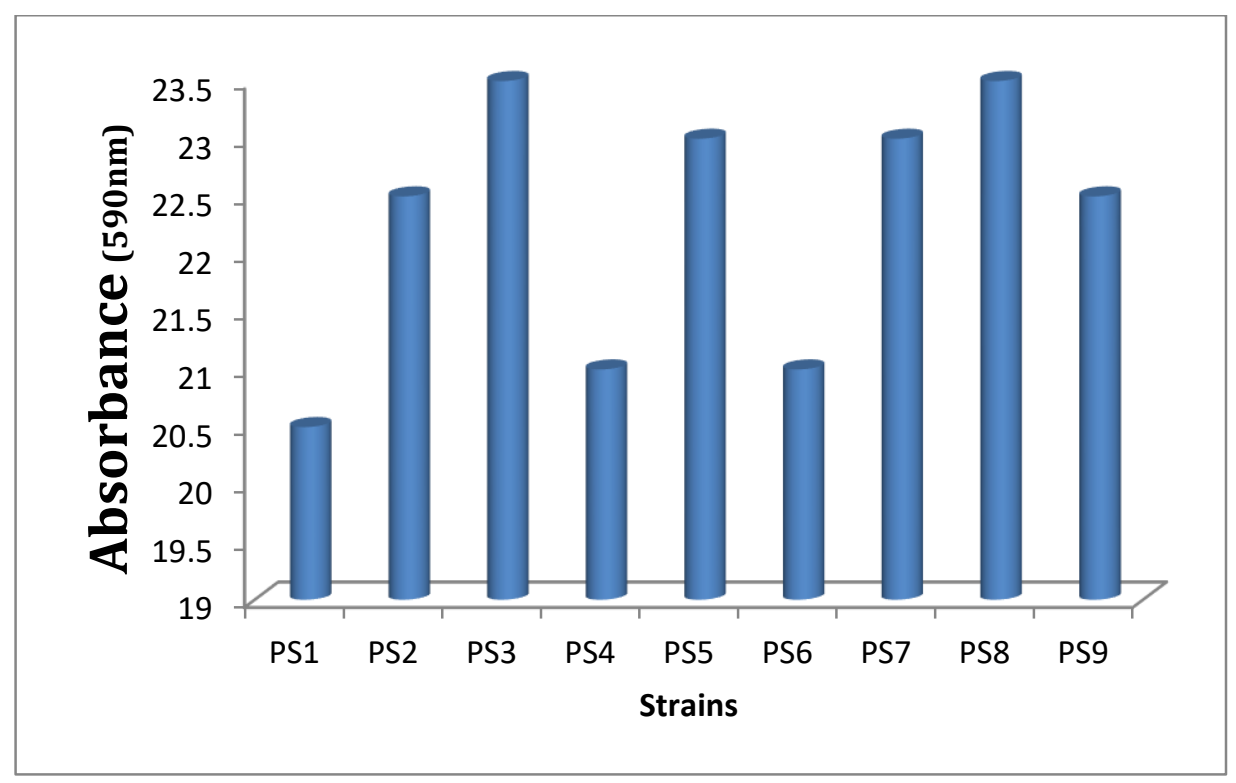

Figure 1: Quantitative Analysis (Absorbance) for Biofilm Formation

Pseudomonas aeruginosa is one of the most frequently found bacterial pathogens in patients with chronic infections, such as chronic wound and cystic fibrosis. The persistence of Pseudomonas in this infection is enabled by its ability to form biofilm. Standard antibiotic treatments, effective against bacteria living as single cells, are generally unsuccessful against biofilm. The presence and persistence of biofilms on chronic skin wounds can affect cellular ( leukocytes, keratinocytes endothelial cells, and fibroblasts ) function, the inflammatory cellular response, cutaneous innate immune response, and the repair phase and may be slow to produce overt symptoms. Once established, however, biofilm infections often persist.

Neutrophils are among the first inflammatory cells to populate the initial wound site and contribute to wound healing by removing bacteria, foreign material, necrotic tissue, and releasing cytokines to promote revascularization and fibrosis. However, prolonged presence of neutrophils 
delays wound healing through the release of inflammatory factors, oxygen species, and proteinases (elastase and cathespsin G) that degrade extracellular matrix and key protein involved in the wound healing cascade causing collateral damage to neighboring healthy host tissue. Keratinocyte migration is reduced in the presence of neutrophils. A study of human chronic venous leg ulcers showed that P. aeruginosa containing wounds ad significantly higher number of neutrophils compared with $\mathrm{S}$. aurues containing wounds.

The roles of macrophages in wound healing are complicated. Although macrophages may not be required in embryonic or neonatal wound healing, there are important in mediating wound healing. Macrophages are dependent o the wound microenvironment in which they are located. Most in vivo investigation of macrophages response to biofilm are performed in foreign body associated infection, in which macrophages are key component (Marcia et al., 2013).

Most knowledge of medical biofilms was derived from studies of Pseudomonas aeruginosa ad Staphylococcus aurueus. In 2008, Kirketerp-Moller et al; when examining wound specimens from 22 patients using the PNA_Fish method, found P.aeruginosa within the tissue samples aggregated as microcolonies imbedded in alginate, that is, biofilm. In the same year Bjarnsholt et al. analyzed sections of chronic wound using fluorescent In-Situ Hybridization techniques and identified distinct microcolonies, confirming the basal structure of bacterial biofilms. In 2010, Kennedy et al found evidence of biofilms in the ulcerate areas of burn wounds using light and electron microscopy techniques. Microbial nature of wound infections which also support biofilm presence in chronic venous leg ulcers, Fazli et al, used PNA -FISH and Confocal laser scanning microscopy (CLSM) on biopsy samples to detect bacteria and large aggregates of cells. Utilizing inflammatory markers, the researchers concluded that P. aeruginosa biofilms lead to the influx of high numbers on neutrophils and biofilms may be one of the main factors leading to a persistent inflammatory response, with a resultant impairment of wound healing. A further study by Han diversity within chronic wounds epiflouresence microscopy revealed the presence of highly organized thick confluent biofilms and $47 \%$ of specimens had significant biofilm coverage arranged as aggregating conies of varying size.

\section{Conclusion}

The data derived from human clinical studies make clear that biofilm have an important adverse effect on wound healing. Despite this, more fundamental scientific studies are required to understand what biofilm do to normal wound healing processes from cellular and immunological perspective. In particular, there is a need for more studies to understand why some wounds with biofilm growing in them heal and other do not. However, in conducting appropriate large randomized controlled trails on biofilms is possible to view biofilms when biopsies are analyzed microscopically. 


\section{References}

Beaudoin, T., Zhang, L., Hinz, A. J., Parr, C. J., \& Mah, T. F. (2012). The biofilm-specific antibiotic resistance gene ndvB is important for expression of ethanol oxidation genes in Pseudomonas aeruginosa biofilms. Journal of bacteriology, 194(12), 3128-3136.

Caiazza, N. C., Merritt, J. H., Brothers, K. M., \& O'Toole, G. A. (2007). Inverse regulation of biofilm formation and swarming motility by Pseudomonas aeruginosa PA14. Journal of bacteriology, 189(9), 3603-3612.

Christensen, G. D., Simpson, W. A., Younger, J. J., Baddour, L. M., Barrett, F. F., Melton, D. M., \& Beachey, E. H. (1985). Adherence of coagulase-negative staphylococci to plastic tissue culture plates: a quantitative model for the adherence of staphylococci to medical devices. Journal of clinical microbiology, 22(6), 996-1006.

Costerton, J. W., Stewart, P. S., \& Greenberg, E. P. (1999). Bacterial biofilms: a common cause of persistent infections. Science, 284(5418), 1318-1322.

Dunne Jr, W. M. (2002). Bacterial adhesion: seen any good biofilms lately?. Clinical microbiology reviews, 15(2), 155-166.

Gupta, S., Agarwal, S., Sahoo, D. R., \& Muralidharan, S. (2011). In vitro production of biofilm in a flow cell system in a strain of Pseudomonas aeruginosa and Staphylococcus aureus and determination of efficiency of ciprofloxacin against them. Indian Journal of Pathology and Microbiology, 54(3), 569.

Gurung, J., Khyriem, A. B., Banik, A., Lyngdoh, W. V., Choudhury, B., \& Bhattacharyya, P. (2013). Association of biofilm production with multidrug resistance among clinical isolates of Acinetobacter baumannii and Pseudomonas aeruginosa from intensive care unit. Indian journal of critical care medicine: peer-reviewed, official publication of Indian Society of Critical Care Medicine, 17(4), 214.

Høiby, N., Bjarnsholt, T., Givskov, M., Molin, S., \& Ciofu, O. (2010). Antibiotic resistance of bacterial biofilms. International journal of antimicrobial agents, 35(4), 322-332.

Hsueh, P. R., Ko, W. C., Wu, J. J., Lu, J. J., Wang, F. D., Wu, H. Y., ... \& Teng, L. J. (2010). Consensus statement on the adherence to Clinical and Laboratory Standards Institute (CLSI) Antimicrobial Susceptibility Testing Guidelines (CLSI-2010 and CLSI-2010update) for Enterobacteriaceae in clinical microbiology laboratories in Taiwan. Journal of Microbiology, Immunology and Infection, 43(5), 452-455.

Mah, T. F., Pitts, B., Pellock, B., Walker, G. C., Stewart, P. S., \& O'Toole, G. A. (2003). A genetic basis for Pseudomonas aeruginosa biofilm antibiotic resistance. Nature, 426(6964), 306310.

Moskowitz, S. M., Foster, J. M., Emerson, J., \& Burns, J. L. (2004). Clinically feasible biofilm susceptibility assay for isolates of Pseudomonas aeruginosa from patients with cystic fibrosis. Journal of clinical microbiology, 42(5), 1915-1922.

Sadovskaya, I., Vinogradov, E., Li, J., Hachani, A., Kowalska, K., \& Filloux, A. (2010). Highlevel antibiotic resistance in Pseudomonas aeruginosa biofilm: the ndvB gene is involved

Copyright (C) 2020-2021, Journal of Scientific Research in Medical and Biological Sciences (JSRMBS), Under the license CC BY- 4.0 
in the production of highly glycerol-phosphorylated $\beta$-(1 $\rightarrow 3)$-glucans, which bind aminoglycosides. Glycobiology, 20(7), 895-904.

Stepanović, S., Vuković, D., Hola, V., BONAVENTURA, G. D., Djukić, S., Ćirković, I., \& Ruzicka, F. (2007). Quantification of biofilm in microtiter plates: overview of testing conditions and practical recommendations for assessment of biofilm production by staphylococci. Apmis, 115(8), 891-899.

Zhang, L., Fritsch, M., Hammond, L., Landreville, R., Slatculescu, C., Colavita, A., \& Mah, T. F. (2013). Identification of genes involved in Pseudomonas aeruginosa biofilm-specific resistance to antibiotics. PloS one, 8(4), e61625. 